\title{
Contribution of Remit Economy on Poverty Reduction in Nepal
}

\author{
Uttam Khanal \\ Department of Social Science and Education, Tribhuvan University, Kathmandu, Nepal
}

Email address:

khanaluttam24@yahoo.com

\section{To cite this article:}

Uttam Khanal. Contribution of Remit Economy on Poverty Reduction in Nepal. Humanities and Social Sciences. Vol. 8, No. 5, 2020, pp. 133-144. doi: 10.11648/j.hss.20200805.11

Received: June 15, 2020; Accepted: July 2, 2020; Published: August 31, 2020

\begin{abstract}
The contribution of remit economy and Poverty reduction in Nepal has analysis in this paper and how remittance income is contributing poverty reduction for employment generation. It is considered as the major component which has direct and indirect impact on macro-economic indicators and tried to explore the possibilities of utilizing remittances in the economic development of the country. When the remittance has increase on a family they have household facility with reflects the socioeconomic differences. Such as, Land ownership, occupations incomes and expenditures are determinants for economic growth. Health related activities, educational status and sanitation are taken as human development indicator and information acquiring capacity, increase in awareness about the basic rights and participation in human development program as the basic indicators for empowerment and social inclusion. Productive utilization of remittances would be necessary for reducing poverty. It carried out discussed only poverty alleviation in relation to the economic growth. There is no doubt that remittance provides reliable source of foreign exchange. It could lead to stable macro-economic indicators and enhances living standard at the household level. Only addressing poverty relating remittances with standard of living would not satisfy the sustainability and economic growth but on the sustainability aspect at both national level and households' level is very scanty. Social impacts of migration, both positive and negative are lacking. The contribution of remit economy has increase of income and the trade deficit and naturally contributes to the Balance of Payments. It also helps to making trade balance and contributed in the development efforts on an average income, expenditure and the capital formation.
\end{abstract}

Keywords: Remittance, Remit Economy, Poverty Reduction, Gross Domestic Product, Employment

\section{Introduction}

The history of remit economy and remittance has began after the British-India and Nepal war during 1814 to 1816. Nepalese youths used to be recruited in the British national army. The volumes of remittance increased only after 1995, when the civil conflict destroyed the local labor markets and people started looking for overseas employment. The political turmoil blocked the industrial expansion and halted plenty of small medium enterprises (SMEs) all over the country reducing job opportunities.

Remittances contribute for over 10 percent of GDP in Bangladesh and the Philippines, over 20 percent of GDP in Nepal, Samoa and Tonga and 51 percent in Tajikistan [1]. The known evidence of migration starts with the British India, the formal entrance of Nepalese to India is believed to begin. 4,656 Nepalese recruited in the British Gurkha regiment is the first accounted evidence of Nepalese employed in India from after 1814-15 war. At the same time large number of Nepalese migrated to India for better employment opportunity in tea-estates of Darjeeling and woodworks of Assam. Later on increasing number of migrants started working as watchmen. Since, the First World War, Nepali youth have continually migrated to foreign countries in search of livelihood.

Annual Report of Department of Foreign Employment, 2018/19 shows that 384,665 populations have entered into Foreign Employment through formal channel, was inthe fiscal year 2011/2012, which had increased to 612,685 in the fiscal year 2018/2019. During 1989/90 remittance income in Nepal was Rs. 676.8 million. This was equal to about half the country's income from tourism and equaled around one seventh of the export economy. In 1990s, the official value of remittance economy was put at 2.9 billion Nepali Rupees [2]. 
The official record of Nepal Rastra Bank shows a dramatic increment in the incoming remittance. It increased considerably from Rs. 549.7 millions in 1990/91 to about Rs. $343,636.1$ million in 2011/12. Remittance soared, particularly after 2001/02. It was Rs. 223466 million increments within 10 years period between fiscal year 2000/01 and 2010/11. It is widely believed that official records for the remittance economy represent just the tip of the iceberg; particularly as most remittances are transferred in formally. Considering the increasing number of workers going outside the country, it was estimated that, at least Rs 50 billons was received in the fiscal year 2001/02 [3].

Along with ever increasing labor migration out of country, the influx of remittance has helped households on smoothening consumption. Out of total remittances, 79 percent is spent on daily consumption followed by loan repayment (7 percent), purchase of household property and other expenditure (8.6 percent) and investment in education ( 3 percent). This pattern indicates that there is a considerable implication on the livelihood of people as a major portion of remittances is spent on consumption. Merely 2.4 percent is spent on capital formation. Besides, contributing for poverty reduction, it has helped on maintaining external macroeconomic stability in the last decade [4]. When one side of labor migration and remittance sets a rosy picture, it has costs too. The easy money syndromes and Dutch diseases, ghost town, moral hazards and decaying moral and social values are implicit cost that economy is bearing due to labor migration. The deaths, injuries and curtailed leisure can't be easily valued yet costs significantly and immeasurably to the economy and society [5].

\section{Statement of the Problem}

Despite ever increasing size of remittances in the country, there has been little effort to analyze its effect on economic development, especially on poverty reduction in Nepal. It is observed that little attention has been paid to examining the impact of remittances on households, despite ever increasing size of official records of remittances. In fact, notwithstanding that remittance has been implicated as a vital source of income with crucial income smoothening effect and contribution to improve standard of living, its effect in Nepal is not known. Thus, because of poor understanding of the impact of remittances in Nepal's economy and national development, remittances are poorly managed. It is observed that in spite of the recognized advantages of well articulated remittance management regime to aid growth and development by providing much needed foreign exchange and as a source of liquidity and a palliative for its balance of payment deficit; Nepal does not put remittance of migrant workers to their best use. This is indicated by Nepal Rastra Bank data, on utilization of remittances income out of total remittances, $79 \%$ is spent on daily consumption. Thus, the key policy questions would be:

a) What are the sources of remittances in Nepal?

b) How remittance is reduced poverty in Nepal? c) How is remittances income contributing in National economy development?

d) What is the contribution of remittance in rural household income?

\section{Objectives of the Study}

The study has coverage the following objectives which are:

a) To analyze the contribution of remittances for poverty reduction.

b) To examine the role of remittances for household income and Socio-economic development.

\section{Rationale and Limitation}

It is already known that there are numbers of potential effects of remittances on poverty reduction, even though proper and specific studies are not carried out till now about the positive impact of remittances on household level poverty. Further research is needed to gain a more precise understanding of the patterns of remittance use in Nepal. Information, as in many other areas, is the precondition for fact-based decision making, which is lacking in matters concerning migration. This study aims to reduce information gaps and increase knowledge and understanding of remittance phenomena. The current financial crisis with its unprecedented job losses and potential for long duration had added extra burden on the poorest countries and the migrants themselves. Large numbers of migrants returning to their countries as their job opportunities have suddenly vanished. Therefore, it is high time to formulate specific policies regarding migration and productive utilization of remittances. For this purpose, framework for assessing the impact of remittances is developed to consider positive and negative impacts at all levels are the rationale of this of this study.

This study has limited to the migrant workers working in the foreign Countries without India so country migration has not considered and there were many poverty indicators. Information regarding poverty reduction was generalized by extrapolating the information collected from the study areas and targeted communities. Non-cash remittances are not considered in the study, Poverty line considered in the study is based on expenditure data, calories basis for poverty line is not considered and caste and Gender are ignorable considerations.

\section{Review of Literature}

The data on remittance is mainly macro level based on household surveys and results of their effects are quite variable depending on setting, country or migrant group studied. This hinders general inference. Moreover, measuring remittances is a difficult task since most of the money remitted goes through informal channels and is not recorded in official accounts.

Determinants of Remittances: The basis for the current discussion and extensions on motives those migrants haveto 
remit was set by in their work on The New Economics of Labor Migration. They had explained the causes behind the migrants' decisions to send funds (cash and non cash) to their relatives back home. Generally, the motives behind remittances can be categorized under as the altruistic motive, the self-interest motive and implicit family contract, loan repayment and co-insurance.

Altruistic Motive envisages that incremental income of the migrants is send back home owing to affection and responsibility towards the family. It is assumed in this model that sending remittances brings satisfaction to the migrant out of a concern for the welfare of his family. Remittances can vary based on the number of household members that migrate and the poverty status of the receiving household; although it has been shown that poorer households obtain a larger proportion of their total income from remittances than do non-poor ones. Self-Interest Motive assumes that the migrant is primarily stimulated by an economic and financial self-interest, when sending remittances to the home country. The interest of the migrants would be to invest their saving in the home country in property, land and financial assets rather than investing in the host country. Thus, they remit the savings with the interest to accumulate his wealth.

The theory implicit family Contract: Loan Repayment and Co-Insurance of remittances assumes that there will be implicit contract between the migrant and those who stay at home. The contract is a combination of the elements of investment and repayment. As per the loan repayment theory the family invests in the education of the migrant and usually finances the costs of migrating as travel and subsistence costs in the host country. This is the loan (investment) element of the theory. The repayment part happens after the migrant settles in the foreign country and his income profile begins to rise over time and is in a position to begin repaying the loan such as principal and interest back to the family in the form of remittances. For a household as a whole, there may be a Pareto-superior strategy to allocate certain members as migrants, and remittances should be the mechanism for redistributing the gains. The theory suggests that the family can function as an insurance company that provides members with protection against income shocks by diversifying the sources of income. On the other hand, the families also work as a bank that finances migration for some members. The borrowers remit funds in order to repay the loans, which are put toward more loans to further the interests of other individual family members.

The total pool has of remittance income and the decision whether or not to remit, the amount to remit, the way to remit and the uses of remittance incomes. The macroeconomic factors in this framework are: number of workers, wage rates, economic activity in host country, economic activity in sending country, exchange rate, relative interest rate between labor-sending and receiving countries, political risk factors in sending country and facility of transferring funds. Besides that years since out migration, household income level, employment of other household members, marital status, level of education, and occupational level of migrants are microeconomic factors are also included in this framework.

Remittances and its Uses: The empirical evidence on the use of remittances is quite diverse and even contradicting, mainly because the studies on this issue only consider one country at a time. The way in which remittances are used, is what determines their effect on the economy. It is observed that if remittances are investment into productive sectors like: education and health they have positive growth effects through increased output and productivity. On the other hand, if they are spent only on consumption, their effects depend on whether the consumed goods are locally produced or imported. If they are locally produced, a multiplier effect is observed when remittances are invested in local production and thus, have an indirect contribution to growth by encouraging investment in related industries. But, if they are spent on imported consumer goods, besides the positive multiplier effect on the economy they also tend to have a negative effect on the balance of payments.

As stated earlier that the primary motive for remitting money is altruism. This directly implies that remittances are compensatory income for remittance. It is thus, logical to assume that most remittances are mainly spent on consumption of daily necessities. This is supported by numerous studies: From a household survey in Mexican communities Massey and Parrado found that two thirds of remittances go to consumption mainly on food and maintenance followed by housing. Similar spending patterns are found by for Pakistani households.

The Migration and the development of source areas have evidence from China, shows that a significant part of remittances go to investments and savings. In the case study of the Fuijan province of China (the home town of half a million international migrants), Zhu finds that migrants are core agents in the development of the region, mainly through investments in physical and human capital. It is observed that the dramatic development of China in the last decades has mainly been concentrated along its coastal areas. Although this may be attributed to many factors, including its favorable location, it is noteworthy that Chinese overseas and Chinese in Hong Kong, Macao and Taiwan have been the major sources of foreign investment in China [6].

Similarly, Mausuri [7] in a study based on the Pakistan Rural Household Survey (PRHS) finds that remittances are indeed invested in physical capital such as farm machinery and agricultural land, tractors and tube wells, as well as human capital such as schooling and early childhood growth. Egypt is another example where remittances have been used in investment and productive activities. Returnees are responsible for 15 percent of the capital invested in small enterprises and 15 percent of the associated employment generation. As far as savings are concerned, development theory maintains that the propensity to save out of transitory income is higher than the propensity to save out of permanent income, Ample empirical evidence shows that saving out of remittances, which are considered as temporary income, is indeed much higher than savings from regular earnings in the home country. 
The pessimistic view on migrants role in development [8] argue that because the majority of remittances are used for consumption, they are not considered as being used in productive investment. However, not only directly invested remittances should be considered as investments. Expenditure on education and health are in fact investments in human capital and are very likely to increase productive capacity in the long run. Moreover, if remittances are saved in financial intermediaries they are loaned to investors, thus indirectly contributing to productive investment. An important characteristic of remittances is that they are fungible by nature they free up other resources. So even if remittances are not directly used for investment by the households receiving this money, they can free the households' other resources to finance investment. Having said that altruism and self interest are the main determinants of remittances and that remittances are used primarily for the provision of basic needs but also invested in productive activities, there is no doubt that remittances improve the standards of living for the receiving households. The critical question is whether they have a positive growth/development effect on the receiving economy as a whole.

The Bangladesh Government has established the Ministry of Expatriates' Welfare and Overseas Employment in 2001 to ensure welfare of the expatriate workers and increase of the overseas employment [9]. The Ministry has been rendering ceaseless efforts in enhancing the flow of remittance and to provide equal opportunity for the people of all areas of the country for overseas employment and ensuring overall welfare of the migrant workers. Government has also undertaken different savings and investment facilities like US Dollar Premium Bond, Wage Earners Development Bond, tax holiday and tax exemptions for nonresident Bangladeshis. Philippine government has cited some deliberate efforts to channel remittances towards economic and social development. In order to harness the remittances towards productive investments, National Reintegration Program was initiated to encourage migrants and their families to venture into productive and sustainable economic undertakings that emphasize on wealth creation and make the migrants stay home and keep the family integrated and, at the same time, help stimulate economic activities in local communities. The program helped to expand the country's micro, small and medium enterprises and create employment-generating opportunities for the unemployed and the vulnerably employed [10].

"Integrating migration and development strategy" observed that although the majority of remittances are sent by individuals, a small part is sent by collective Diasporas organizations, Hometown Association (HTA) which is linked to a specific area such as a village. There is evidence that villages connected to HTAs tend to have better roads, electricity and employment opportunities. These associations encourage migrants by providing incentive to save and invest. Mexican state of Zacatecas is an example of the HTA project where each dollar contributed in remittances is matched by three dollars in which one from the municipality, one form the state and one from the federal government.

The uses of remittances were not universal in all parts of migrant-sending communities. However, observes the investment made by migrants fundamentally depends on the migrants' legal rights in destination countries, the household's income, and the specific political and economic conditions in the countries of origin. In some cases, remittances have enabled migrants to invest in land and cattle [11], and in other cases remittances have generally not been dedicated to agricultural improvements and overwhelmingly invested in housing and land [12]. Similarly, while in some cases most remittance-driven investments have remained within the sending region.

In the context of Nepal, the studies carried out so far have been very limited, despite the fact that Nepal stands as one of the major remittance-recipient countries in the world. The two most reported uses of remittances received in Nepal are: "for daily consumption" and "repayment of the loan". About 79.9 percent of the total remittances received by the households is used for daily consumption while 7.1 percent is used for loan repayment. Other uses are to acquire household property 4.5 percent and education 3.5 percent. Only a small percentage of the remittances 2.4 percent are used for capital formation and the remaining 2.5 percent is used for other purposes. Three Years Plan was Approach Paper [13] of the National Planning Commission has indicated domestic borrowings as a major means to financing the budget deficits. Its working policy in the Public Debt Management section has provision for issuing Remittance Bond to make foundation for the priority sectors. But, fixation of priority sectors for the investment of collected fund through the Remittance Bond is the main challenges on the way of sustainable development.

Similarly, in Nepal the annual budget in July 2009 announced that the government would issue a Diasporas Bond to raise funds for infrastructure development for the first time. The budget speech by foreign minister on 12 July 2011 announced that for investing remittances income in the productive sectors and encouraging the investment a High level taskforce will be formed to prepare proposal along with the Action Plan for National Investment. Ministry of Finance has issued Procedural Guideline for Foreign Employment Bond, 2011 aiming at utilizing the migrant's remittance earning for infrastructure development of the country.

The research work "International Labor Migration of Nepalese Women, The Impact of their Remittances on Poverty Reduction" observed the mixed impacts on the children of migrant mothers in Nepal: positive impacts were seen on the opportunities for education, health care and lifestyle but worsening psychology of their children as their mothers apart for a long time. By being able to earn an income, support the family financially and have the freedom of financial decision-making, traveling to foreign countries with new experiences, seeing new places, and meeting with people from different parts of the world and interacting with them brings the feeling of independence and confidence for the migrants and this effect impart to their immediate family 
as well.

Contribution of Remittances in Economic Development: This section of the literature review presents the contribution of remittances in economic development in international, South Asian and Nepalese context. In the research work "The contribution of remittances to growth", investigated the impact of exogenous shocks of remittances on consumption, investment, imports and output in five Mediterranean countries.

The study "Workers' Remittances and Economic Growth in China and Korea: An Empirical Analysis", investigated the relationship between workers' remittances and economic growth in China and Korea. Annual time series data over the period of 1980 to 2009 was employed to analyze the long run, short run relationships and robustness of the results respectively using [14] co-integration technique, error correction model, and sensitivity analysis.

Co-integration results confirm that there exist significant positive long run relationship between remittances and economic growth in Korea, while, significant negative relationship exist between remittances and economic growth in China. Error correction model confirms the significant positive short run relationship of workers' remittances with economic growth in Korea while, the results of China were insignificant in short run. Causality analysis confirms unidirectional causality runs from workers' remittances to economic growth in both China and Korea. Sensitivity analysis confirms that the results are robust. [15] In "Can monetary policy enhance remittances for economic growth in Africa? The case of Nigeria", evaluated the role of monetary policy in enhancing remittances for economic growth in Nigeria. The study aimed at empirically verifying the linkage between monetary policy actions and the flow of remittances and identifying the strategies which monetary authorities needs to adapt to direct remittances to productive investments.

In their work "Increasing the Macroeconomic Impact of Remittances on Development" reviewed the recent country experiences on the impact of remittances on poverty, growth, real wages and external competitiveness, and provided available policy options for developing countries to deal with the consequences of large and persistent remittance inflows. Major findings of this review were the stability of recipient economies by compensating for foreign exchange losses due to macroeconomic shocks; reduce poverty in the recipient economy and resulted in better development outcomes in many low-income countries. The paper is however inconclusive regarding the effect of remittances on long-term growth. Large outflow of workers (especially skilled workers) can reduce growth in countries of origin. Large remittance inflows can lead to exchange rate appreciation and lower export competitiveness [16].

"Bangladesh, Towards Accelerated, Inclusive and Sustainable Growth Opportunities and Challenges and the Economics of Labor Migration and Remittances in Bangladesh" quotes that the direct contribution of remittances to Bangladesh's national income (GNI) has grown rapidly in the past decade. Remittances reached 10.5 percent of GDP in fiscal year 2011. Remittance growth peaked at 32.4 percent in fiscal 2008 after which growth declined as rapidly as it had risen [17].

The regression analysis shows that remittances are not driven exclusively by the need for family support but also by the migrants' skill and education level and motivation to transfer their savings as investment in their home country. At household level remittances contributed 63 percent of total household expenditures, which is on an average Tk 98,708 per annum per household or more than 1.5 times its preremittance income. The study shows 81.1 percent of the households uses of remittances for family expenses, 47.8 percent in celebration of Ed festival, 42.6 percent in Paying off debt, 34.2 percent in medical treatments and likewise. Only 7.1 percent of the remittances are saved and spend 29.8 percent for children's education.

Regarding the development impact of remittances extends beyond the narrow definitions of poverty. Poverty headcount rates of remittance receiving households in Bangladesh are 61 percent lower than the poverty headcount rate of households who do not receive remittances. Several econometric models used show that remittance has a propoor effect in Bangladesh. Most of the short-term Bangladeshi migrant workers are from low-income families in rural areas.

In her article assessed the contribution of foreign employment and remittances to Nepalese economy. The paper examined the data covering the period 1990/91 to 2005/06 published by NRB, DLEP, NPC and CBS. The paper admits that the remittances sent home by migrant workers is a boon to the economy. Remittances have emerged as one of the premier sources of foreign exchange, and an important avenue of support for family members remaining at home. It has been already demonstrated that remittances sent by the migrant workers is an effective tool for poverty reduction [18].

In his paper on "The Impact of Migrant Remittances on Income Distribution and Welfare in Nepal" identified source of remittances as an equalizer of income distribution and inducer of a higher gain in welfare. The study is based on data of NLSS 1995 and 2004. Nationally representative sample of 3,912 households were used for the study. The survey defines remittance as a transfer income in cash and inkind received by households. The effect of remittance on household income distribution was identified by comparing income inequality with and without remittance; and by decomposition total income in equality by income source. Decomposition of income sources identifies the contribution of each income sources to overall inequality; and it also shows the effect of a small percentage change in any income component to total inequality [19].

The study concluded that remittances have contributed to equalize the income distributions at the two extreme groups. The remittance from India is the main factor for the marginal improvement of income distribution in the poorest group, while the remittance from abroad is the main contributor in equalizing income distribution in the richer group. Likewise, 
a slight improvement could be observed in urban income distribution after remittances are included in household income but Lorenz ranking of rural income distributions, with and without remittance is ambiguous; they cross each other.

Remittances and poverty reduction in South Asian has paper on "Impact of remittances on poverty in developing countries", points out that though there is a growing literature on the impact of remittances on development, very few studies have empirically estimated the impact of remittances on development in general, and on poverty in particular, in the developing countries. It undertakes a case study of India and estimates the impact of remittances on poverty in India, which has been one of the top recipients of remittances in 2008. It also undertakes a more micro-level analysis by estimating impact of remittances on poverty in Kerala, which is one of the top remittance receiving states in India.

In the paper on "Remittances and Poverty Nexus: Evidence from Pakistan" aims to explore the various factors affecting poverty with particular emphasis on the relationship between poverty and foreign remittances. It is hypothesized that remittances, trade openness, GDP growth, inflation, urbanization and tax rates are the possible variables affecting poverty. The remittances-poverty nexus is tested both for the short-run as well as for the long-run. Fully modified ordinary least square (FMOL) technique is used for establishing shortrun and long-run relationship between poverty and its determinants [20]. The period selected is from 1973-2006. Log-linear modeling specification is utilized in present data of impact of remittances on poverty reduction. The data is acquired from different sources like International Financial Statistics, World Development Indicators and Economic Survey of Pakistan of various issues. Acharya C. P. and Roberto (2012), study on "The Impact of Remittance on Poverty and Inequality: A Micro-Simulation Study for Nepal" tried to show how impacts of remittances vary with the regional 'incidence' and maturity of the migration process and with the country-source of remittance.

The paper work on "Migration and Poverty Reduction in Nepal", aimed to measure the impact of increased remittance inflows on the economic well-being of Nepali households between 1995 and 2004. More specifically, the study models the effect of remittances and work migration on household consumption and aggregate poverty and inequality rates [21].

Two rounds of the NLSS data were used to estimate the household consumption function. The survey had followed the Living Standard Measurement Survey (LSMS) methodology developed by the World Bank for both rounds. The national level simulations indicate that remittance decreases the head count poverty by 2.3 percent and 3.3 percent in the first round of the survey, and between 4.6 percent and 7.6 percent in the second round. It reduces even further the depth (at least 3.4 percent and at most 10.5 percent) and severity (at least 4.3 percent and at most 12.5 percent) of poverty.

The study is based on the data from two rounds of the Nepal Living Standard Survey (NLSS). The NLSS is a nationally representative survey of households and communities conducted between June 1995 and June 1996 (NLSS-I) and April 2003 and April 2004 (NLSS-II) by the Nepal Central Bureau of Statistics with the assistance of the World Bank. The survey's sample covers 73 districts of Nepal (excluding the Rasuwa and Mustang districts). The NLSS-I sample includes information on 3,373 households in 274 PSUs, while the NLSS-II sample is based on 326 crosssectional and 95 panel PSUs enumerating 3,912 and 1,160 households, respectively.

Total per capita consumption expenditure is taken as an indicator for measuring household welfare. Our consumption aggregate includes monthly household expenditures on food and non-food items, imputed housing expenditures, an imputed stream of services from durables goods, as well as cash expenditures and imputed expenditures for goods and services produced by the household itself. The values of home-produced items are calculated as a product of the quantity of each food item and its prevailing local market price. The poverty line for the analysis is constructed using cost-of-basic-needs approach. To assure comparability over time and across the regions, all monetary indicators (household consumption, values of remittances, wages, and so on) are deflated to 2004 all Nepal prices. The cost of the poverty basket in 2004 all Nepal prices equals NRs 7,694 per year per person equivalent to US\$107 or US\$590 in PPP [22].

The remittances are not invested in productive sectors, and spent only on consumption, are two different views regarding utilizations of remittances. Many household surveys around the world claims that two thirds of remittances go to consumption- mainly on food and maintenance followed by housing. On the other hand, the study conducted in China claims that migrants are core agents in the development of the Fuijan province of China. Here, it is claimed that remittances are invested in physical and human capitals. Rural household survey in Pakistan found that remittances are indeed invested in physical capital such as farm machinery and agricultural land, tractors and tube wells, as well as human capital such as schooling and early childhood growth. Egypt is yet another example where remittances have been used in investment and productive activities. Return migrants are responsible for 15 percent of the capital invested in small enterprises and 15 percent of the associated employment generation. For the case of Nepal, the two most reported uses of remittances received are: "for daily consumption" and "repayment of the loan" About 79.9 percent 7.1 percent of the remittances received respectively.

There have been very few observations that government around the world had made efforts in utilizing the remittances income in productive investments. Bangladesh and the Philippine government have shown some deliberate efforts to channel the remittances towards economic and social development. Different savings and investment facilities for non-resident Bangladeshis, and National Reintegration Program for productive and sustainable economic undertakings in the Philippine are some of the examples. Nepal has issued Foreign Employment Bond, 2011 aiming at 
utilizing the migrant's remittance earning for infrastructure development of the country.

It is considered that international migration and remittances significantly reduce the level, depth, and severity of poverty in the developing world. Various studies shows that remittances help lift households out of poverty. Remittances contributed to widen the economic disparities across regions, and money flows improved the well-being of poor households even in the lagging regions. Regarding costs and benefits of migration, receiving remittance is the most obvious benefit for sending countries. Remittance provides reliable source of foreign exchange, remittances lead to stable macro-economic conditions. Key costs related to migration described are Macro-economic costs the potential for Dutch disease, individual costs, Social exclusion and Deterioration of key social services.

\section{Methods}

Remit economy and remittance income as an earning from foreign employment, works as one of the driver for poverty reduction. The conceptual frame given that foreign employment and the remittances send back home, if properly utilize will contribute in reducing poverty, both in terms of head count indexes and inequalities. It is expected that remittances earning increases the economic status of the migrant's household which enables the member for seeking good education, better health facilities/services and nutritious food. This will lead to the development of human resources. Once the basic needs of the human beings are fulfilled, as per the Maslow's need hierarchy theory, human tends to seeks for social needs. Thus, need for social inclusion and empowerment will follow. Thus, Economic security, Human Resources Development, and Empowerment and social inclusion are considered as immediate proper utilization of remittances income. The long run impact of the remittances at micro level would be improvement of accessibilities. Access to resources, social structure and further access to education, health services will lead to improvement in standard of living. Thus, reducing the poverty head count rate and inequalities. This will contribute in capital formation such as increasing contribution to gross domestic product, increase in foreign exchange and ultimately favorable Balance of Payment. As a long term impact of the remittances income, it is expected to increase circular flows of income and expenditure resulting in substantial reduction in poverty head count rate and inequalities in the country.

The secondary information were collect from data on remittances, consumptions and investments published in various publications of Nepal Rastra Bank, Ministry of Finance, National Planning Commission, Central Bureau of Statistics, and Department of Foreign Employment, and also from the Ministry of Labor and Transport have been taken into consideration. Data over the periods 2006/07 to 2016/17 has been used for estimating the contribution of remittances on other variables of macro level economic indicators. Possibilities of fulfilling the national resource gap through remittance income are explored by analyzing the data.

This study has mainly based on secondary sources of information was used. Primary information was used into the socio-economic status of household. The remittance has receiving and non-receiving income on poverty reduction. The information has analysis with descriptive technique to assess the impact of remittances on poverty reduction and national economy development. Relation between the remittances and gross domestic product was studied by comparing the remittance's share in increase of household income.

\section{Discussion and Analysis}

Migration and Remittances: Migration of people from one place to another is a usual phenomenon since the beginning of human civilization. The migration in the beginning was for the sake of food and exploring new places for security purpose. But gradually the migration took the shape in diverse forms and now has become a very essential and common in each and every corner of the world. Millions of people from around the world especially from the developing world are leaving their usual place of residence for seeking better employment opportunities and supply of food for their dependents. With globalization, the trend of people going from one place to another has intensified. Poverty and the inability to earn enough or produce enough to support oneself or a family are major reasons behind the movement from one place to another. These are not only characteristics of migration from poor to rich states; poverty also fuels movement from one developing country to others, where work prospects seem-at a distance, at least-to be better International migration: the movement of people across international boundaries has enormous implications for growth and welfare in both origin and destination countries. Globally, more than 215 million people of 3 percent of the world population live outside their countries of birth, and over 700 million migrate within their countries [23].

International migration boosts world incomes by allowing workers to move to where they are more productive. Migration results in an increase in aggregate output and income. Remittances generally reduce the level and severity of poverty and frequently lead to higher human capital accumulation; larger health and education expenditures; greater access to information and communication technologies, improved formal financial sector access, small business investment and entrepreneurship and reduced child labor and help households to be better prepared for adverse shocks such as droughts, earthquakes, and cyclones. Remittances to developing countries have reached $\$ 372$ billion in 2011, an increase of 12 percent over the previous year, [23]. The true size, including unrecorded flows through formal and informal channels, is believed to be significantly larger. Recorded remittances are more than twice as large as official aid and nearly two-thirds of foreign direct investment and flows to developing countries.

Remittances sent home by migrants to developing 
countries are three times the size of official development assistance and can have profound implications for development and human welfare. Remittances can contribute to lower poverty and to the building up of human and financial capital for the poor. Efforts have been made to develop migration and remittances as a financing instrument for national development purposes. It has been realized that diaspora bonds can be a powerful financial instrument for mobilizing diaspora savings to finance specific public and private sector projects, as well as to help improve the debt profile of the destination country.

Nepalese people gradually started entering into foreign job markets. Nepal's economy is circumscribed by poverty and stagnation, which is further engulfed by low level equilibrium trap due to prolonged conflict, inefficiency and corruptions. Macroeconomic indicator exhibit that the size of Gross National Income is found to be relatively diminutive US\$ 8.1 billion and gross national income per capita is inordinately low US\$ 311 per year as of WDR, 2008. Economic growth rate is confined to 2.5 percent, lowest in South Asian Region. Around 31.0 percent of the total population live below the poverty line in object poverty and 24.1 percent population receive less than US\$ 1 a day. Foreign Direct Investment (FDI) stagnated and siphoned off with the closure of a number of joint ventures in recent times (WDR, 2008). The balance of trade with India and overseas countries is growing excessively negative, but with favorable balance of payment situation. Fiscal and budget deficits are pressing hard to accelerate the quantum of internal and external borrowings. Saving/Gross

Domestic Product (GDP) ratio declined while investment/GDP ratio moderately increased in recent years. Currently Index illustrates that share market is rising steadily against the back drop of prolonged conflict leading to downswing of the economy. However, revenues are buoyant, international reserves have sustained increasing trends, and remittances significantly swelled up over the years, particularly due to growing demand for foreign employment at international labor market. Labor market is highly encapsulated by informal sector with poor contribution of manufacturing sector to GDP, and human resources lack quality, efficiency and competitiveness to match at domestic and international labor market and maximize benefits from globalization.

At present the total population of Nepal is 28 million in 2006 which is estimated to be 32.7 million by 2015 . The average annual growth rate of population was 2.3 percent as of Population Census 2001, and it is estimated to be 1.9 percent for the period 2005-15. The size of Labor force was estimated to be 11.4 million in 2007 . The average annual growth rate of labor force aged 15 and older remained was 2.6 percent during 1990 2007. This exhibits that each year approximately 300,000 labor forces will be added in the labor market. Of the total labor force, around 200,000 are estimated to be absorbed in foreign employment, and remaining 100,000 to be employed in domestic labor market [24].
Data provided by Department of Labor, Nepal in 2007 shows that, an average of 284 persons go to the Gulf Countries and Malaysia every day with the formal approval. The figures of foreign employment till March 2007 published by Department of Labor (DOL), Ministry of Labor and Transport Management (MOLTM) indicate that, it is growing rapidly resulting in huge amount of remittance estimated to be to the tune of US\$ 1.5 billion. The number of workers going abroad for employment has been steadily increasing gas per the data provided by the Department of Labor and Employment Promotion.

In 2008/09, the number of workers going overseas for employment was 219965 compared to 2,159 in 1994/95. The detail of number of Nepalese workers abroad is given in the table below: Annex 4.1 gives account of Nepalese migration abroad from 1994/95 till 2011/12. During 1989/90 remittance income in Nepal was Rs. 676.8 million. This was equal to about half the country's income from tourism and equaled around one seventh of the export economy. In 1990 the official value of remittance economy was put at 2.9 billion Nepali Rupees [18].

Remittances and Capital Formation: There are so many factors that determine GDP. But for this study purpose, economically active population of the country, gross fixed capital formation and workers' remittances are considered the major factors. The flow of GDP and remittances from the fiscal year 2000/01 to 2011/12 show sever increasing growth. The trend shows that the average growth of remittance is 43.50 percent during 12 years time period. The time series data also shows the percentage contribution of remittance to GDP at current producer's price (MoF, 2012). The data gives the glimpse of GDP from the year 2000/01 till 2011/12 and the corresponding remittance received. Through simple arithmetic calculation it was found that, during the year 2000/01 share of remittance in GDP was 2.22 percent. This share reached to 17.01 percent in 2010/11 and in 2011/12 it has reached 25.05 percent. On an average, the share of remittance to GDP was 13.16 percent during the review period from 2000 to 2012.

Capital formation is the major determinant of economic growth. The purpose of economic development is to build capital equipment on sufficient scale to increase productivity in agriculture, mining, plantation and industries. This is possible only if there is a rapid rate of capital formation in the country, that is, if a larger proportion of income is saved and invested in capital equipment. Capital formation of the country could be measured using various methods. Expenditure method is widely used for calculating capital formation of the country. This method arrives at the Gross Domestic Capital Formation (GDCF) by adding up all the expenditures made on goods and services during a year. Income can be spent either on consumer goods or capital goods. Again expenditure can be made by private individual/households or by government/business enterprises.

To attain at the Gross Fixed Capital Formation (GFCF), expenditures on consumer goods and services made by the private individual/households and government/business 
enterprises are added together. Change in stock and consumption of capital allowances is further added to calculate the GDCF. For the purpose of this study, Gross Fixed Capital Formation (GFCF) has been calculated based on government's and private's investment expenditure. Gross Fixed Capital Formation (GFCF) in the year 2000/01 was Rs. 84,751 million, which has increased to Rs 305,682 million in the year 2011/12.

Economically Active Population: The economically active population is generally defined to "comprise all those persons who contribute to the supply of labor for the production of goods and services disregarding whether they actually were employed at the time of enumeration or not" according to central bureau of statistics 2008. The 2001 census had allowed anyone to counts economically active if they did any work at all during the last 12 months. The extent of economic activity rate is generally measured by crude and refined activity rate. Crude Activity Rate (CAR) represents the number of economically active population as a percent of the total population. Refined Activity Rate (RAR) is a more refined measure of measuring the economically active population. This is simply the activity rate for persons of working age. In the population census 2001, RAR has been defined to represent the number of economically active population of age 10 years and above as percentage of the population of corresponding 10 years and above.

For the purpose of this study, economically active population has been calculated using Crude Activity Rate (CAR). In this method, total population figures, population growth rates and rate of Economically Active Populations indicated in the Population censuses 1981, 1991 and 2001 are taken as the basis for calculating the Economically Active Population. The details of Economically Active Population from the fiscal year $2000 / 01$ to $2011 / 12$ are shown in the table. The time series of the economically active population in the year $2000 / 01$ was $8,792,181$ which have increased to $12,078,891$ in the fiscal year 2011/12.

Remittances and Employment: Imparting knowledge and skills to national human resources in line with national and international labor market to promote employment opportunities is the major responsibility of the government. Currently, in Nepal, 2.5 million people of working age are unemployed and labor participation rate stands at 83.4 percent. Out of the total population, 30 percent is either unemployed or underemployed whereas four hundred thousand people are entering labor market every year [25].

The contribution of foreign employment to reducing unemployment situation and poverty and enhancing Nepalese economy should be considered significant. Foreign employment attracted Nepali youth due to dearth of adequate employment opportunity in the country. Data shows that 384,665 people have gone for foreign employment in the fiscal year 2011/12 Department of employment 2012. About 56 percent families in Nepal have received remittance income in one year. The average household remittance receipt is estimated at Rs. 80,436 million at current prices. This has increased the share of remittance in total family income.

In order to trace the contribution of Foreign Employment in the economic development of the country, Formal Migrant population was compared with Economically Active Population. Time series data shows that Economically Active Population in the country was $8,792,181$ in the fiscal year $2000 / 01$ which has increased to $12,078,891$ along with the population. In the similar pattern number of population going for foreign employment has raised from 55,025 in 2000/01 to 384,665 in 2011/12. This shows that population going abroad for foreign employment is 3.18 percent of Economically Active population in the country in the year 2011/12.

Contribution of Remittances on National Economy: The contribution of remittances on macroeconomic indicators such that national development process can be understood from both micro and macro perspectives. Many studies has been conducted worldwide and concluded that remittances have strong statistically significant negative impact on poverty 10 percent rise in GDP leads to 1.6 percent reduction in people living in poverty.

In Nepalese context also remittances is considered as the major component which has direct and indirect impact on macroeconomic indicators: the GDP, BoP, Consumption and Investment, Foreign Exchange, and Employment (indicators considered for the study). Average share of remittances on GDP was 13.16 percent during the review period from 2000 to 2012. Among so many factors affecting GDP the study considered economically active population, gross fixed capital formation and workers' remittances to explore the relationship. Three modules with specific hypothesis were used to test relationships between dependent variables GDP and the three independent variables- RR, GFCF and EAP. The results of the test show positive effect of RR and GFCF on GDP, whereas EAP has shown no significant impact on GDP. Though, in practice EAP is very important determinant of economic growth, short supply of the labor force due labor migration might have cause decrease in production and productivity.

The study assumes that with the contribution of remittances income to the trade deficit, it naturally contributes to the Balance of Payments. Relationship between the RR and TB and between RR and BoP has been analyzed with the help of Correlation matrix. The matrix shows that there is a statistically significant negative correlation between RR and TB. The magnitude of coefficient of correlation of .975 shows a stronger relationship between them. Similarly, a statistically significant negative correlation between RR and BoP with the magnitude of the coefficient of correlation of .689 shows strength in their relationship.

Overall conclusion of the analysis is that remittances are supporting to strengthen the BoP situation by reducing the effect of negative trade balance. Huge gap between the consumption and saving has hindered the regular development activities of the country. The resource gap between saving and investment is estimated to be Rs. $60,496.0$ million in the fiscal year 2011/12. This has resulted 
into liquidity crisis in the country. Productive investment of the remittance earning could be remedial measure for narrowing the gap. The study tried to explore the possibilities to identify the amount of the remittance earning and specify the sectors for productive investments. For the purpose the study assumed that if, approximately 3 percent of the remittance income had contributed in the development efforts Capital Expenditure on an average remittances amount to 8.3 percent is contributed to the capital expenditure. Composite and diffusion indices were used indentify the possibility of the prediction of remittances income and least square method of forecasting.

Remittance income as the component of the total foreign exchange and present scenario of scoring increase in it has contributed in total foreign exchange of the country. Time series data shows 65.8 percent share of remittance income in the total foreign exchange in the year 2011/12. This shows remittance income if it could be used in productive sector it could contribute in economic development of the nation. The directional relationship between RR and Total Foreign Exchange was tested with the help of Simple Regression analysis. The result shows $\mathrm{R}$ squares 0.991 . It indicates that there is 99.1 percent variation in the TFE accounted for by RR. F statistic of 2307.365 with p-value of .000 , and the beta coefficient 0.996 shows better impact of RR on TFE with the linear relationship between the two. Foreign Employment assumed 384,665 economically active populations in the fiscal year 2011/12 department of employment 2012. Comparison of Migrant population and Economically Active Population shows 3.18 percent contribution in creating employment. Simple regression analysis was run to examine the relationship between EAP and FE. The F test result of 109.425 shows nearly 91 percent of the variation in EAP. Foreign employment has positive linear relationship with EAP.

The analysis above shows that remittances are an important source of fund for the growth of national economy. It provides the foreign exchange needed for importing scarce inputs and also provide additional savings. But, magnitude of the developmental impact of remittances on the receiving countries is often depends on how this money is spent. This demands the investment of remittances income in productive sector. However, even the disposition of remittances on consumption and real estate may produce various indirect growth effects on the economy. These include the release of other resources to investment and the generation of multiplier effects.

Poverty trends and reduction: There are many important dimensions of poverty in Nepal. Poverty issues have received national policy attention from time to time. Ever since the inception of planned development, poor areas have been a priority for policy makers at least on paper. Public distribution of food grains in poor mountain and hill districts, initiation of a remote area development program and from the Fourth Plan 1970 to 1975 , the formulation of regional development strategies are important landmark sin policy addressing poverty and inequality issues in the country.
Overtime many changes in rural development approaches have been introduced.

However a shift from area based approach to people based focus concerned with the worsening plight of children and women, and hitherto unaddressed issues of discrimination, and exploitation of ethnic groups, indigenous people and others disadvantaged members of the society commenced only after the restoration of multiparty democracy in Nepal, the increase in Maoist conflict and the emergence of poverty reduction as a major global priority. The first attempt to estimate poverty in Nepal was in made 1976/77. During that year, the National Planning Commission of Nepal (NPC/N) carried out a national survey on Employment, Income Distribution, and Consumption Pattern in Nepal. The poverty level was specified in terms of basic minimum calorie intake. This level was 2250 calorie per capita per day on average. The 1976/77 NPC survey specified the annual per capita income poverty line at Rs. 720 (Rs. 540 for food and Rs. 180 for non-food).

The Nepal Rastra Bank (NRB) carried out a Multipurpose Household Budget Survey (MPHBS) in 1984/85 using Rs. 1971 as a cut-off line to separate those falling below the poverty line. Later, the Central Bureau of Statistics (CBS) of the NPC/N conducted the Nepal Living Standard Survey (NLSS I) in 1996. Though the CBS Survey in 1996 did not specify a poverty line, the World Bank study in 1999 specified it at Rs. 4404. Along with the NLSS II and III three data sets of poverty data and poverty lines are available to study Nepalese poverty for the last two decades.

Poverty in Nepal is largely considered as rural phenomenon. It has various economic and non-economic dimensions. The Tenth Plan 2002 to 2007, which was also the PRSP, had divided poverty into three broad categories income poverty, human poverty and social exclusion. Absence of high, sustainable and broad-based economic growth, exclusion of the masses of the poor from the mainstream of development process, slow improvements in the indicators of human development, low productivity and dependence of agriculture on climate, increasing pressure of population growth and ineffective governmental administration were the prime causes of poverty incidence in Nepal.

To achieve the goal of poverty eradication emphasis was given to sustainable and broad based economic growth. It was assumed that this will foster the economic opportunities and its distribution to different sectors. Investment in the social sector was expected to create conducive environment for uplifting back ward groups. The economic growth has plan emphasized on self employment creating, income earning and protective programs which will directly benefit to the economically, geographically and socially backward groups, castes, disabled and helpless people and people living below poverty line. Economic growth is considered the primary wheel for poverty alleviation. The concept of high, sustainable and broad-based was not limited only to the economic growth. To attain the high, sustainable and broadbased economic growth; agriculture, forest, industry and water resources were to be developed maximally, where the 
employment and income generating opportunities were maximum. Domestic and export oriented industries were to be given priority while developing these sectors. To increase rural employment and income generation, agriculture sector were to be commercialized. Special emphasis were to be given on the service sector mainly tourism, communication and information technology, finance and housing, construction and transportation. Similarly, to reduce production cost, productivity growth strategy was to be taken as a campaign. For this appropriate technology were to be encouraged.

Role of public sector were to be as a facilitator and referee in those sectors where private sector is interested. But, the strong and direct role of government was to be established in the backward and remote areas, oppressed caste, group, and areas where the private investment is not attractive. For policy transparency; favorable environment was to be created; by which local bodies, private and other sectors play effective role in development process. To make development process sustainable and transparent, local bodies and private sector were to be promoted.

\section{Conclusion}

There is no doubt that migration and remittance has positive as well as negative impact to the receiving country. Nepalese remittance could be considered major component of GDP and plays a vital role in increasing economic growth of the nation. Share of remittance in GDP during the year 2001/02 was 10.3 percent. This share reached to 22.05 percent in $2011 / 12$ respectively. On an average, the share of remittance to GDP was 13.16 percent during the review period from 2000 to 2012. Recent GDP growth figures indicated in Nepal has been annually growing in real terms in $2011 / 12$ and $2012 / 13$ are at 4.48 percent and 3.56 percent respectively. But, the present economic scenario shows persistent energy shortage, labor problem, and uncertainties in investment climate for facilitating businesses, manufacturing industries and service sector promotion. As a result, it is very apparent that the country's infrastructure, housing and public services, and public utilities water and electricity supply are all major obstacles to the kind of sustainable economic development that can combat poverty and raise living standards among those on lowest incomes.

There is no evidence of studies that reflects remittances income with poverty reduction efforts. Poverty has always been considered as rural phenomenon with economic and non economic dimensions. PRSP emphasizes on selfemployment creating, income earning and protective programs which will directly benefit to the economically, geographically and socially backward groups, disabled and helpless people and people living below poverty line. But the effectiveness of the program has been challenged by weak formulation of policy, programs and projects, ineffective targeting, poor service delivery, and weak monitoring and evaluation system. Poverty is often defined by one dimensional measure, such as income. Poor people do not just suffer from a lack of income. No one indicator alone can capture the multiple aspects of poverty. Multidimensional Poverty provides more complete picture of poverty within a country or a community than is available from headcount measures alone. It advocates addressing poverty into three broad categories income poverty, human poverty and social exclusion.

The conclusion of summarize it would be appropriate to say that the remittance income earned from foreign employment is helping the households of the study area in fulfilling their basic needs as well as fulfillment of other socio- economic aspect of their life. Therefore, it is clear that the remittance is playing very positive role to the respondents and their family to reduce the poverty level of the study area. It is also considerable that remittance income has raised consumerism, which tends to be nonsustainable unless this income is channelized into the main stream of macro economic development. Long term economic growth of the country is the only mean for sustainable impact of the remittances income on poverty. Government of Nepal need to improve investment climate to increase job opportunities to ensure remittances income be invested productively.

\section{References}

[1] GFR. (2013). Impact of remittance income on poverty reduction, Report of Nepal Rastra Bank.

[2] Bank. (2008). A study on remittance income from India. Research Department, Nepal Rastra Bank.

[3] Khatri, S. K. (2007). Labor migration, employment and poverty alleviation in South Asia, presented in the Proceedings of the Regional Seminar.

[4] Nepal Rastra Bank (2011). Quarterly Economic Bulletin, Vol. 45, No. 1 and 2 Mid January 2011: Nepal Rastra Bank, Kathmandu; Also available in the http://www.nrb.org.np

[5] Bhattarai, P. C. (2012), Remittances ko hisabkitab matrai nakhojaun, Kantiput Daily year 20, issue 221, page 7, Sept. 26, 2012.

[6] Zhu, Y. (2006). Migration and the development of source areas: Evidence from China. Chapter 11- in how migration can benefit development.

[7] Mausuri, G. (2007). Does work migration spur investment in origin communities? Entrepreneurship, schooling, and child health in rural Pakistan. Chapter 3, International Migration, Economic Development and Policy edited by Caglar Özden, Maurice Schiff.

[8] Massey, D. S., Parrado, E. (1994), Migra dollars: The remittances and savings of Mexican Migrants to the United States. Population research and policy review, 13: 3-30.

[9] Hasan, R. Al. (2006). Harnessing remittances for economic development of Bangladesh, International Network of Alternative Financial Institutions Bangladesh Working Paper Series, and no 1. 
[10] Vries S. D. (2011). Mobilizing the use of remittances towards poverty reduction and economic and social development through government initiatives: The Philippine experience, Expert Meeting on Maximizing the Development Impact of Remittance, Geneva, 14-15 February 2011.

[11] Vanwey, L. K. (2005). Land ownership as a determinant of international and internal migration in Mexico and internal migration in Thailand. International Migration Review, 39 (1), pp. 141-172.

[12] Jokisch, B. D. (2002). Migration and agricultural change: The case of smallholder agriculture in Highland Ecuador. Human Ecology, 30 (4), pp. 523-550.

[13] Nepal Rastra Bank. (2012). Quarterly Economic Bulletin, Vol. 47, No. 1 Mid October 2012: Nepal Rastra Bank, Kathmandu; Also available in the http://www.nrb.org.np 281.

[14] Syed Tehseen, J. \& Syed Ali Raza. (2012). Workers' remittances and economic growth in China and Korea: An empirical analysis, Journal of Chinese Economic and Foreign Trade Studies, Vol. 5 Issue: 3.

[15] Mbutor, O. Mbutor. (2010). Can monetary policy enhance remittances for economic growth in Africa? The case of Nigeria, Research Department.

[16] Ratha, D. \& Mohapatra S. (2007). Increasing the macroeconomic impact of remittances on development. Development Prospects Group, the World Bank, 2007.

[17] World Bank. (2013). End poverty South Asia. The World Bank, Also Available in the blogs. World Bank .org/end poverty south Asia.
[18] Shrestha, B. (2008). Contribution of foreign employment and remittances to Nepalese economy. Research Division, Nepal Rastra Bank.

[19] Subedi, M. K. (2010). The impact of migrant remittances on income distribution and welfare in Nepal, Four-Monthly Statistical Bulletin, Year-32, Vol. 99 No 1, Central Bureau of Statistics, 2010.

[20] Kalim, R. \& Mohammad, S. (2009). Remittances and poverty nexus: Evidence from Pakistan, International Research Journal of Finance and Economics, Euro Journals Publishing, Inc. 2009, Also available in the http://www.eurojournals.com/finance.htm

[21] Lokshin, M., Mikhail, \& Elena. (2007). Work-related migration and poverty reduction in Nepal, World Bank Policy Research Working Paper 4231, May 2007.

[22] World Bank. (2006). Remittances and economic development in Somalia. The World Bank, Social Development Paper No.

[23] World Bank. (2012). Bangladesh: Towards accelerated, inclusive and sustainable growth opportunities and challenges, Chapter 2: The Economics of Labor Migration and Remittances in Bangladesh.

[24] International Labor Organization. (2004). an overview paper on overseas employment in Nepal. Kathmandu. 2004.

[25] Nepal Rastra Bank. (2013). Impact evaluation of remittances: A case study of Dhanusha district, Banking Development and Research Unit, Janakpur, 2012. 